\title{
The Importance of lodine Supplementation and Smoking for Maternal and Fetal Thyroid Health in Pregnant Women
}

\author{
Mustafa Dinc ${ }^{a}$ Mustafa Cakar ${ }^{b}$ Sevket Balta ${ }^{c}$ Muharrem Akhan ${ }^{b}$ Hakan Sarlak $^{b}$ \\ Sait Demirkol ${ }^{\mathrm{c}}$ \\ ${ }^{\mathrm{a}}$ Department of Internal Medicine, Beytepe Military Hospital, and Departments of ${ }^{\mathrm{b}}$ Internal Medicine and \\ 'Cardiology, Gulhane Medical Academy, Ankara, Turkey
}

Dear Editor,

We read the article 'Relative impact of iodine supplementation and maternal smoking on cord blood thyroglobulin in pregnant women with normal thyroid function' by Hiéronimus et al. [1] with great interest. The authors concluded that iodine supplementation does not significantly impact cord blood (CB) thyroglobulin $(\mathrm{Tg})$ in healthy nonsmoking pregnant women selected for normal thyroid function, as opposed to smoking women, and stated that CB Tg appears to be a marker of in utero tobacco exposure. They proposed that in areas of mild iodine deficiency, iodine supplementation could especially benefit the fetuses of smokers. We would like to thank the authors for their contribution which we believe will be a source of inspiration for further studies.

Once-daily prenatal vitamins should contain $150-200 \mu \mathrm{g}$ iodine. $250 \mu \mathrm{g}$ daily iodine intake is recommended during pregnancy and in the lactation period. The adequacy of the iodine intake during pregnancy can be assessed by measuring urinary iodine concentration, which should ideally range between 150 and $250 \mu \mathrm{g} / \mathrm{l}$ [2]. In the presented study, $150 \mu \mathrm{g} /$ day iodine supplementation was started in the first trimester. We think this dose may be regarded as inadequate iodine supplementation. In addition, urinary iodine excretion in the third trimester was significantly lower in smokers, but this finding was not discussed properly. In another study among women of childbearing age, urinary iodine excretion in heavy cigarette smokers was found to be increased, and an association was observed between smoking and hypothyroxinemia [3]. It was advised that iodine supplementation in smoking women of childbearing age should be done carefully.

Because impaired renal function may affect urinary iodine excretion, renal function in the presented study could have been assessed at least with serum creatinine levels or with spot urine analysis. Also, smoking has been proposed to decrease not only anti-Tg but also anti-TPO, and therefore smoking might reduce the risk of thyroid autoimmunity $[4,5]$. In the presented study, the authors indicated only the status of anti-Tg. Serum cotinine levels in smokers increase in direct proportion to the amount of cigarettes smoked per day [6] The smoking status of the subjects in the presented study (never smokers, ex-smokers, etc.) is specified and cotinine has been assayed, but any adjustment for cigarette smoking by type (in terms of the level of nicotine) is not specified.

We think the study would have gained in strength if parameters considered as risk factors for thyroid disease (like low TSH, anti-TPO positivity, history of miscarriage, etc.) [7] had been discussed in more detail. Though the importance of iodine supplementation for pregnant and fetal thyroid health is well known, further studies are needed to reveal the effects of maternal smoking.

\section{Disclosure Statement}

The authors have no conflicts of interest to disclose.

$\begin{array}{ll}\text { KARGER } & \begin{array}{l}\text { ๑ 2013 European Thyroid Association } \\ \text { Published by S. Karger AG, Basel } \\ 2235-0640 / 13 / 0023-0211 \$ 38.00 / 0\end{array} \\ \begin{array}{l}\text { E-Mail karger@karger.com } \\ \text { www.karger.com/etj }\end{array} & \end{array}$

Dr. Mustafa Dinc

Department of Internal Medicine

Beytepe Military Hospital

Ahlatlibel St., TR-06800 Cankaya-Ankara (Turkey)

E-Mail dr.mustafadinc@yahoo.com 


\section{References}

1 Hiéronimus S, Ferrari P, Gal J, Berthier F, Azoulay S, Bongain A, Fénichel P, BruckerDavis F: Relative impact of iodine supplementation and maternal smoking on cord blood thyroglobulin in pregnant women with normal thyroid function. Eur Thyroid J 2012;1: 264-273.

- 2 De Groot L, Abalovich M, Alexander EK, Amino N, Barbour L, Cobin RH, Eastman CJ, Lazarus JH, Luton D, Mandel SJ, Mestman J, Rovet J, Sullivan S: Management of thyroid dysfunction during pregnancy and postpartum: an Endocrine Society clinical practice guideline. J Clin Endocrinol Metab 2012;97: 2543-2565.
3 Vanderver GB, Engel A, Lamm S: Cigarette smoking and iodine as hypothyroxinemic stressors in US women of childbearing age: a NHANES III analysis. Thyroid 2007;17:741746.

4 Männistö T, Hartikainen AL, Vääräsmäki M, Bloigu A, Surcel HM, Pouta A, Järvelin MR, Ruokonen A, Suvanto E: Smoking and early pregnancy thyroid hormone and anti-thyroid antibody levels in euthyroid mothers of the Northern Finland Birth Cohort 1986. Thyroid 2012;22:944-950.

5 Pedersen IB, Laurberg P, Knudsen N, Jørgensen T, Perrild H, Ovesen L, Rasmussen LB: Smoking is negatively associated with the presence of thyroglobulin autoantibody and to a lesser degree with thyroid peroxidase autoantibody in serum: a population study. Eur J Endocrinol 2008;158:367-373.
6 Olivieri M, Poli A, Zuccaro P, Ferrari M, Lampronti G, de Marco R, Lo Cascio V, Pacifici R: Tobacco smoke exposure and serum cotinine in a random sample of adults living in Verona, Italy. Arch Environ Health 2002;57:355-359.

7 Horacek J, Spitalnikova S, Dlabalova B, Malirova E, Vizda J, Svilias I, Cepkova J, Mc Grath C, Maly J: Universal screening detects two-times more thyroid disorders in early pregnancy than targeted high-risk case finding. Eur J Endocrinol 2010;163:645-650. 